\title{
PENGENALAN WAJAH MENGGUNAKAN LOCAL BINARY PATTERN (LBP) DAN SUPPORT VECTOR MACHINE (SVM)
}

\author{
Khusnil Mujib*), Achmad Hidayatno, dan Teguh Prakoso \\ Departemen Teknik Elektro, Universitas Diponegoro \\ Jl. Prof. Sudharto, SH, Kampus UNDIP Tembalang, Semarang 50275, Indonesia \\ ${ }^{*}$ E-mail: khusnilmujib136@gmail.com
}

\begin{abstract}
Abstrak
Terdapat banyak metode yang digunakan untuk mengenali identitas seseorang, misalkan nomor unik, kartu identitas dan sandi rahasia. Kekurangan metode-metode tersebut antara lain, kartu dapat hilang, nomor unik dan sandi rahasia dapat terlupakan. Salah satu solusi untuk masalah ini adalah sistem identifikasi seseorang berdasarkan metode biometrik jenis fisiologis. Penelitian ini merancang sebuah sistem untuk mengidentifikasi wajah. Citra wajah diambil menggunakan kamera web kemudian diekstraksi cirinya dengan metode local binary pattern (LBP). Ciri wajah yang diperoleh diklasifikasi menggunakan support vector machine (SVM). Model terbaik SVM dibangun berdasarkan validasi silang grid search. Kernel linier terbaik dibentuk dengan $\mathrm{LBP}_{8,2}^{\mathrm{u} 2}$ dan parameter $\mathrm{C}=10^{5}$. Kernel radial basis function (RBF) terbaik dicapai dengan $\mathrm{LBP}_{16,2}^{\mathrm{u} 2}$ dan parameter $\mathrm{C}=10^{3}$ dan $\gamma=10^{2}$. Berdasarkan pengujian terhadap keseluruhan citra wajah, akurasi kedua kernel adalah 96,0\%. Pada pengujian lima ekspresi wajah dengan SVM kernel linier, akurasi 100,0\% diperoleh untuk ekspresi sedih, netral dan mata tertutup. Sedangkan SVM kernel RBF menghasilkan akurasi 100,0\% untuk ekspresi terkejut, netral dan mata tertutup. Hasil pengujian tersebut menunjukkan sistem pengenalan wajah yang dirancang telah berfungsi baik.
\end{abstract}

Kata kunci: pengenalan wajah, local binary pattern, support vector machine, validasi silang grid search

\begin{abstract}
There are many methods to recognize a person's identity, e.g. unique number, ID card, and password. The methods have some weaknesses, e.g. ID can be lost, unique number and password can be forgotten. One of solution to these problems is recognition system based on physiological biometric. This Research designs a system to identify human face. Face images are taken using webcam and then local binary pattern (LBP) is employed for feature extraction. The obtained face features are classified using support vector machine (SVM). The best models are built based on grid search cross validation. The best linier kernel is constructed with $\mathrm{LBP}_{8,2}^{\mathrm{u} 2}$ and parameter $\mathrm{C}=10^{5}$. The best radial basis function (RBF) kernel is achieved with $\mathrm{LBP}_{16,2}^{\mathrm{u} 2}$ and the parameters $\mathrm{C}=10^{3}$ and $\gamma=10^{2}$. Test to all images using both kernels produces an accuracy of $96.0 \%$. In test based on five facial expressions shows that linier kernel achieves an accuracy of $100,0 \%$ in sad, neutral and closed eyes and RBF kernel obtains an accuracy of $100,0 \%$ for shocked, neutral and closed eyes. The results of these tests show that the face recognition system works well.
\end{abstract}

keywords: face recognition, local binary pattern, support vector machine, grid search cross validation.

\section{Pendahuluan}

Manusia sebagai individu mempunyai ciri yang khas. Ciri tersebut dapat digunakan sebagai pengenal atau identitas seseorang. Konsep identifikasi adalah mengenali seseorang dari komponen yang dimilikinya contohnya kartu, dari kode yang diketahuinya contohnya sandi dan password identity number (PIN), dari ciri alami (biometrik) contohnya wajah, iris mata, dan sidik jari, atau dari kombinasi ketiganya.
Biometrik adalah ciri-ciri yang dimiliki oleh individu yang dapat diukur. Terdapat beberapa ciri yang sering digunakan dalam pengenalan biometrik. Beberapa diantaranya adalah pengenalan sidik jari, pengenalan wajah, pengenalan suara, dan pengenalan iris [1]. Pengenalan wajah merupakan suatu pengenalan pola (pattern recognition) yang khusus untuk kasus wajah. Local Binary Pattern (LBP) merupakan suatu metode ekstraksi ciri tertentu yang merupakan karakteristik suatu citra, dalam hal ini adalah wajah. 
Penelitian terdahulu yang berkaitan dengan pengenalan wajah menggunakan beberapa metode diantaranya, sistem pengenalan wajah menggunakan metode $2 D$-discrete cosine transform (2D-DCT) dan support vector machine (SVM) [2] dan untuk penelitian yang berkaitan dengan LBP yaitu perbandingan pengenalan ekspresi wajah menggunakan SVM, gabungan principal component analysis (PCA) dengan SVM dan gabungan PCA, SVM, dan LBP [3].

Berdasarkan hal di atas tersebut, maka Penelitian ini merancang sebuah sistem untuk mengidentifikasi atau mengenali wajah. Masukan yang digunakan adalah sebuah citra wajah yang diambil menggunakan webcam. Proses ekstraksi ciri untuk memperoleh karakteristik atau ciri wajah tersebut dengan menggunakan metode LBP. Beberapa tahap prapengolahan ditambahkan sebelum melakukan proses ekstraksi ciri pada citra wajah, antara lain: mengubah ukuran citra, mengubah citra berwarna (RGB) menjadi citra aras keabuan, peningkatan kualitas citra, dan pemotongan area citra wajah. Tahap-tahap prapengolahan ini ditambahkan untuk meningkatkan akurasi pengenalan serta mempercepat proses ekstraksi ciri. Pengenalan atau identifikasi menggunakan metode SVM untuk menentukan dikenali atau tidaknya citra wajah sebagai nama individu yang telah dilatih dalam model klasifikasi SVM. Seluruh citra wajah yang digunakan sebagai data latih dan citra uji dilakukan dengan pengambilan data menggunakan webcam dengan posisi dan ekspresi wajah yang berbeda.

\section{Metode}

\subsection{Diagram Blok Sistem}

Sistem dirancang untuk mengenali wajah dari suatu citra wajah secara otomatis. Pengenalan wajah yang diterapkan memakai metode Local Binary Pattern (LBP) dengan klasifikasi Support Vector Machine (SVM). Selain itu, sistem yang dirancang juga menerapkan metode ViolaJones untuk deteksi wajah. Masukan dari sistem ini adalah citra atau video wajah yang diakuisisi menggunakan kamera. Jenis kamera yang digunakan adalah sebuah kamera web dengan merk Logitech c525 yang memiliki resolusi kamera sebesar 8 megapiksel. Dari citra yang telah diakuisi tersebut akan diolah dan dikenali oleh sistem sebagai wajah. Spesifikasi sistem pengenalan wajah yang akan dicapai adalah akurasi $100,0 \%$ untuk pengujian data latih dan akurasi $\geq 90,0 \%$ untuk pengujian dengan data uji. Jumlah citra latih yang digunakan sebanyak 375 dari 15 individu yang berbeda. Sedangkan jumlah citra ujinya adalah 75 dengan rincian tiap individu 5 variasi ekpresi (netral, mata tertutup, gembira, sedih, terkejut). Citra uji juga divariasikan terhadap derau dengan jenis derau Poisson untuk mengetahui kinerja sistem.
Sistem pengenalan wajah ini terdiri dari 2 proses utama yaitu pelatihan dan pengenalan. Diagram bloknya bisa dilihat pada Gambar 1.

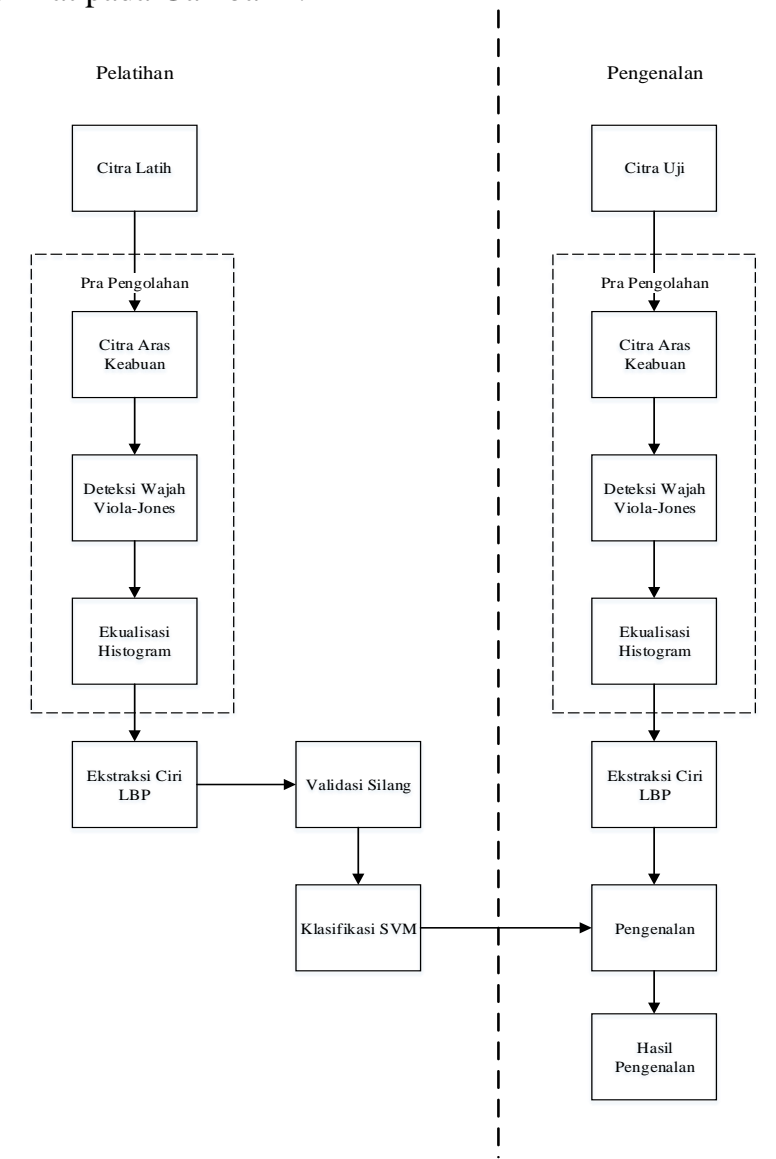

Gambar 1. Diagram blok sistem pengenalan wajah

\subsubsection{Pelatihan}

Pelatihan terdiri dari Prapengolahan, ekstraksi ciri, validasi silang, klasifikasi SVM. Sebelum citra wajah diekstraksi ciri proses prapengolahan dilakukan terlebih dahulu baik pada data latih maupun data uji. Hal ini dikarenakan hasil dari prapengolahan dapat meningkatkan akurasi pengenalan serta mempercepat proses ekstraksi ciri. Tahap prapengolahan ini antara lain mengubah citra RGB menjadi citra aras keabuan, pemotongan area wajah citra dan peningkatan kualitas citra dengan ekualisasi histogram. Hasil dari prapengolahan ini adalah citra wajah dengan aras keabuan yang sudah siap untuk diekstraksi cirinya. Metode LBP akan mengekstraksi ciri citra wajah dan menghasilkan vektor ciri. Langkah selanjutnya adalah validasi silang, pada klasifikasi SVM terdapat beberapa parameter yang harus dioptimalisasi sehingga menghasilkan model klasifikasi yang terbaik. Jika parameter sudah didapat maka model klasifikasi SVM sudah dapat dibangun. Model ini nantinya yang digunakan dalam proses pengenalan. 


\subsubsection{Pengenalan}

Proses pengenalan merupakan sebuah proses pengambilan keputusan dikenali atau tidaknya sebuah citra uji terhadap model klasifikasi yang sudah dilatih. Tahapan pengenalan hampir sama dengan pelatihan yaitu, Prapengolahan, ekstraksi ciri, pengenalan. Prapengolahan pada pengenalan sama seperti pada proses pelatihan, yaitu mengubah citra RGB menjadi citra aras keabuan, pemotongan area wajah citra dan peningkatan kualitas citra dengan ekualisasi histogram. Setelah melalui proses prapengolahan, citra diektraksi ciri menggunakan metode LBP. Vektor ciri hasil ekstraksi ciri akan diklasifikasi menggunakan model klasifikasi yang sudah dilatih untuk menentukan hasil pengenalan dari citra wajah tersebut.

\subsection{Deteksi Wajah Metode Viola-Jones}

Metode Viola-Jones adalah algoritma pendeteksi objek berdasarkan algoritma pembelajaran AdaBoost menggunakan ciri Haar [4]. Metode ini banyak digunakan untuk mendeteksi objek karena memiliki algoritma yang efisien, sehingga tidak memerlukan waktu lama untuk melakukan proses pendeteksian objek. Terdapat empat kontribusi pada metode Viola-Jones, yaitu:

1. Ciri Haar yaitu ciri persegi sederhana yang digunakan untuk mendeteksi ciri dari bagian tertentu wajah

2. Integral Image untuk menghitung ciri Haar dengan cepat.

3. Metode AdaBoost machine-learning untuk memilih ciri Haar yang spesifik yang akan digunakan.

4. Pengklasifikasi Bertingkat (Cascade Classifier) sebagai pengklasifikasi akhir untuk menentukan daerah wajah pada suatu citra.

\subsection{Metode Ekstraksi Ciri Local Binary Pattern (LBP)}

Terdapat beberapa metode untuk mengekstraksi ciri yang paling berguna dari citra wajah untuk melakukan pengenalan wajah. Salah satu metode ekstraksi ciri adalah metode local binary pattern (LBP). Pendekatan ini diperkenalkan oleh Ojala dkk [5] pada tahun 1996. Tekstur dan bentuk citra digital dapat dideskripsikan menggunakan LBP.

Operator LBP asli bekerja dengan delapan piksel tetangga, menggunakan nilai piksel pusatnya sebagai threshold seperti pada Gambar 2.

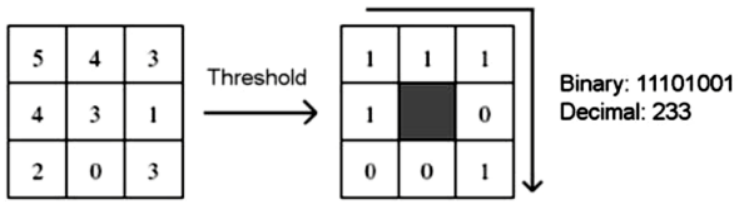

Gambar 2. Operator LBP asli
Jika koordinat dari piksel pusat adalah $\left(x_{c}, y_{c}\right)$ maka koordinat dari tetangga $\mathrm{P}\left(x_{p}, y_{p}\right)$ pada tepi lingkaran dengan jari-jari R dapat ditentukan dengan:

$$
\begin{aligned}
& x_{p}=x_{c}+R \cos \left(\frac{2 \pi p}{P}\right) \\
& y_{p}=y_{c}+R \sin \left(\frac{2 \pi p}{P}\right)
\end{aligned}
$$

Jika nilai keabuan dari piksel pusat adalah $g_{c}$ dan nilai dari tetangganya adalah $g_{p}$ dengan $p=0, \ldots, \mathrm{P}-1$, maka nilai LBP untuk piksel $\left(x_{c}, y_{c}\right)$, dapat dicari menggunakan,

dengan,

$$
L B P_{P, R}\left(x_{c,} y_{c}\right)=\sum_{P=0}^{P-1} s\left(g_{p}-g_{c}\right) 2^{P}
$$

$$
s(x)= \begin{cases}1, & x \geq 0 \\ 0, & x<0\end{cases}
$$

LBP disebut seragam jika memiliki paling banyak perpindahan dua bitwise dari 0 ke 1 , atau sebaliknya, sehingga pola yang seragam memiliki pola tanpa perpindahan atau dua perpindahan. Jumlah kemungkinan pola dengan dua perpindahan adalah $P(P-1)$. Pola seragam dengan titik cuplik $\mathrm{P}$ dan jari-jari $\mathrm{R}$ digunakan notasi $L B P_{P, R}^{u 2}$.

LBP seragam memiliki dua kelebihan. Kelebihan pertama adalah hemat memori, dengan pola tak seragam terdapat $2^{P}$ kemungkinan. Pada $L B P_{P, R}^{u 2}$ terdapat $P(P-1)+3$ kemungkinan pola. Jumlah pola yang mungkin dari tetangga 16 piksel (interpolasi) adalah 65.536 untuk LBP dan 243 untuk $L B P^{u 2}$. Kelebihan kedua adalah $L B P^{u 2}$ hanya mendeteksi tekstur lokal yang penting, seperti titik, akhir garis, tepi, dan ujung.

\subsection{Metode Klasifikasi Support Vector Machine (SVM)}

Konsep SVM dapat dijelaskan secara sederhana sebagai usaha mencari hyperplane terbaik yang berfungsi sebagai pemisah dua buah kelas pada input space. SVM berbeda dengan neural network yang berusaha mencari hyperplane pemisah antar kelas. Hyperplane merupakan suatu pemisah dari 2 kelas data yang berbeda, pada 1 dimensi hyperplane disebut titik, pada 2 dimensi disebut garis, pada 3 dimensi disebut bidang, dan untuk dimensi yang lebih tinggi hanya disebut hyperplane saja. Prinsip dasar SVM adalah pengklasifikasi linier, dan selanjutnya dikembangkan agar dapat bekerja pada permasalahan nonlinier.

Klasifikasi data untuk menentukan kelas bergantung terhadap posisi data tersebut dari hyperplane. Proses pelatihan dan klasifikasi menggunakan model SVM dilakukan dengan inner product antara dua vektor data $(\boldsymbol{x})$ menggunakan sutu fungsi kernel $K$. Linier dan radial basis function (RBF) merupakan fungsi kernel yang digunakan pada Penelitian ini. Kedua fungsi kernel tersebut dapat dituliskan sebagai berikut [6]: 
1. Kernel Linier

$$
K\left(\boldsymbol{x}_{\boldsymbol{i}}, \boldsymbol{x}_{\boldsymbol{j}}\right)=\boldsymbol{x}_{\boldsymbol{i}}^{T} \cdot \boldsymbol{x}_{\boldsymbol{j}}
$$

2. Kernel $\mathrm{RBF}$

$$
K\left(\boldsymbol{x}_{\boldsymbol{i}}, \boldsymbol{x}_{\boldsymbol{j}}\right)=\exp \left(-\gamma|| \boldsymbol{x}_{\boldsymbol{i}}-\boldsymbol{x}_{\boldsymbol{j}} \|^{2}\right)
$$

Klasifikasi dilakukan menggunakan salah satu fungsi kernel pada fungsi pengambilan keputusan. Proses klasifikasi membutuhkan data berupa vektor penyangga $\left(\boldsymbol{x}_{\boldsymbol{i}}\right.$, kelas vektor penyangga $\left(y_{i}\right)$, dan pengali lagrangian $\left(a_{i}\right)$ hasil dari proses pelatihan. Fungsi pengambilan keputusan untuk mengetahui kelas suatu data adalah sebagai berikut [6]:

$$
\begin{aligned}
& f\left(\boldsymbol{x}_{\boldsymbol{d}}\right)=\operatorname{sgn} \sum_{i=1}^{n} \alpha_{i} y_{i} \boldsymbol{K}\left(\boldsymbol{x}_{\boldsymbol{i}} \cdot \boldsymbol{x}_{\boldsymbol{d}}\right)+b \\
& 0 \leq a_{i} \leq C
\end{aligned}
$$

Dengan $a_{i}$ merupakan pengali lagrangian dengan nilai yang dibatasi oleh parameter $C$, yaitu trade-off antara margin pada hyperplane dengan kesalahan klasifikasi. Semakin besar nilai $C$ maka akan meningkatkan tingkat kesalahan saat klasifikasi. Sebaliknya semakin kecil nilai $C$ akan menurunkan tingkat kesalahan saat klasifikasi. Jika fungsi pengambilan keputusan menghasilkan nilai $>0$, maka data yang diujikan berada pada kelas 1. Jika fungsi pengambilan keputusan menghasilkan nilai $<0$, maka data yang diujikan berada pada kelas 2. Nilai parameter $C$ atau $\gamma$ pada fungsi kernel dapat dicari menggunakan metode validasi silang grid search.

\subsubsection{Klasifikasi Multikelas One-Versus-Rest}

SVM pertama kali diperkenalkan oleh Vapnik, hanya dapat mengklasifikasikan data ke dalam dua kelas. Namun penelitian lebih lanjut terus dilakukan untuk mengembangkan SVM sehingga bisa mengklasifikasi data yang memiliki jumlah kelas lebih dari dua atau klasifikasi multikelas

Pada metode klasifikasi multikelas One-Versus-Rest, terdapat $k$ model klasifikasi SVM, dengan $k$ adalah banyak kelas. SVM melakukan klasifikasi dua kelas antara satu kelas dengan kelas-kelas lain yang dianggap sebagai satu kelas [7]. Contohnya, terdapat permasalahan klasifikasi dengan 4 buah kelas, untuk pelatihan digunakan 4 buah SVM 2 kelas seperti pada Tabel 1. dan penggunaannya dalam mengklasifikasi data baru dapat dilihat pada Gambar 3.

Tabel 1. Contoh 4 buah SVM 2 kelas dengan metode OneVersus-Rest.

\begin{tabular}{lrc}
\hline $\boldsymbol{y}_{\boldsymbol{i}}=+\mathbf{1}$ & $\boldsymbol{y}_{\boldsymbol{i}}=-\mathbf{1}$ & Fungsi keputusan \\
\hline Kelas 1 & Bukan kelas 1 & $f^{1}\left(\boldsymbol{x}_{\boldsymbol{d}}\right)=\boldsymbol{w}^{1} \cdot \boldsymbol{x}_{\boldsymbol{d}}+b^{1}$ \\
Kelas 2 & Bukan kelas 2 & $f^{2}\left(\boldsymbol{x}_{\boldsymbol{d}}\right)=\boldsymbol{w}^{2} \cdot \boldsymbol{x}_{\boldsymbol{d}}+b^{2}$ \\
Kelas 3 & Bukan kelas 3 & $f^{3}\left(\boldsymbol{x}_{\boldsymbol{d}}\right)=\boldsymbol{w}^{3} \cdot \boldsymbol{x}_{\boldsymbol{d}}+b^{3}$ \\
Kelas 4 & Bukan kelas 4 & $f^{4}\left(\boldsymbol{x}_{\boldsymbol{d}}\right)=\boldsymbol{w}^{4} \cdot \boldsymbol{x}_{\boldsymbol{d}}+b^{4}$ \\
\hline
\end{tabular}

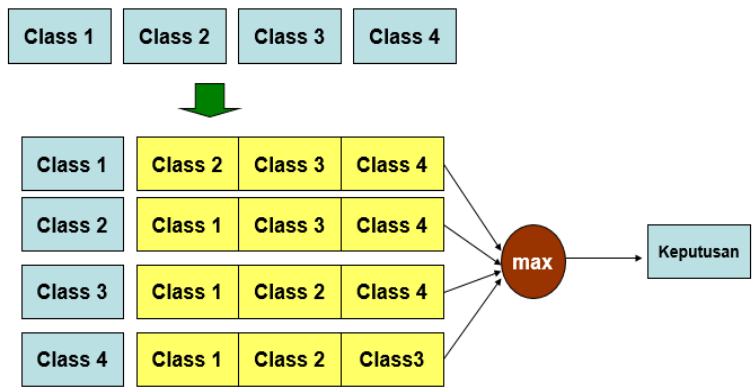

Gambar 3. Contoh klasifikasi dengan metode One-VersusRest.

Berdasarkan Gambar 3, kelas dari suatu data $\boldsymbol{x}_{\boldsymbol{d}}$ ialah kelas yang mempunyai nilai maksimal terhadap fungsi keputusan yang dinyatakan oleh persamaan (7).

$$
\text { class } x=\arg \max \boldsymbol{w}^{k} \cdot \boldsymbol{x}_{\boldsymbol{d}}+b^{k}
$$

\subsection{Validasi Silang Grid Search}

Teknik validasi silang dengan grid search dilakukan dengan membangun suatu model klasifikasi yang mampu mencari nilai optimal pada suatu variabel. Model tersebut dibangun menggunakan variabel dengan rentang nilai tertentu. Model akan mencoba menguji suatu data menggunakan nilai tersebut. Data yang digunakan dapat diambil dari sebagian data latih, sedangkan sisa data tersebut akan digunakan untuk menguji kinerja model yang telah lolos proses validasi silang.

Proses validasi silang grid search dilakukan dengan cara melatih dan menguji setiap model yang telah dibangun dengan suatu nilai parameter pada kernel tertentu menggunakan data latih yang berisi citra wajah dari masing-masing individu. Data latih akan dibagi ke dalam $K$ bagian secara acak. $K-1$ dari seluruh dataset akan digunakan untuk melatih model pengklasifikasi. Sisa data akan digunakan sebagai data validasi untuk menguji model yang telah dilatih tersebut. Pengujian dilakukan sebanyak $K$ pengujian untuk setiap model. Data akan dirotasi untuk setiap pengujian. Hasil pengujian tersebut berupa rata-rata akurasi dari $K$ pengujian. Proses dilanjutkan dengan cara yang sama menggunakan model lain dengan nilai parameter yang berbeda. Hasil akhir validasi silang grid search berupa rata-rata akurasi untuk setiap model [8].

Proses validasi dilakukan dengan menentukan rentang nilai suatu variabel pada SVM, misalnya $\gamma$ dan $C$ pada SVM kernel $\mathrm{RBF}$ dengan rentang nilai $\gamma=$ $\left(10^{-3}, 10^{-2}, 10^{-1} \ldots, 10^{4}\right) \quad$ dan $\quad C=$ $\left(10^{0}, 10^{1}, 10^{2} \ldots, 10^{6}\right)$. Nilai tertentu yang menghasilkan klasifikasi terbaik akan dipilih. Model dengan nilai variabel yang optimal akan digunakan untuk menguji data latih maupun data uji baru. 


\subsection{Kinerja Sistem}

Pengukuran kinerja sistem dilakukan untuk mengetahui kemampuan sistem dalam mengenali ekspresi wajah sesuai dengan data masukan. Pengukuran kinerja menggunakan persentase akurasi klasifikasi. Akurasi dapat dituliskan sebagai perbandingan antara citra yang diklasifikasikan secara benar dengan keseluruhan citra yang diuji. Tingkat keberhasilan atau akurasi dapat dituliskan sebagai,

$$
\text { Akurasi }=\frac{\mathrm{Jml} \text { citra uji yang dikenali benar }}{\mathrm{Jml} \text { citra uji keseluruhan }} \times 100 \%
$$

\section{Hasil dan Analisa}

Bagian ini membahas berbagai pengujian yang dilakukan pada program yang telah dirancang dan analisis hasil pengujiannya. Bagian ini dilakukan dalam tiga tahap, yaitu pengujian parameter, pelatihan dan pengujian citra. Pengujian parameter bertujuan untuk mencari nilai terbaik pada parameter kernel yang menghasilkan akurasi terbaik. Pelatihan merupakan tahap pelatihan dan pembangunan model pengklasifikasi dengan keseluruhan dataset pelatihan. Pengujian citra digunakan untuk menentukan identitas dari pemilik citra wajah.

\subsection{Pengujian Parameter}

Pengujian parameter dilakukan dengan mencari parameter LBP dan SVM terbaik. Bagian ini menggunakan data latih wajah sebagai masukan. Data tersebut akan diekstraksi ciri dengan variasi jumlah titik dan jari-jari LBP, kemudian diolah menggunakan validasi silang grid search dengan variasi kernel dan parameter kernel. Parameter terbaik hasil validasi silang akan digunakan dalam pelatihan SVM. Hasil akhir dari bagian pengujian parameter adalah model pengklasifikasi yang dapat digunakan untuk mencari identitas atau nama individu dari suatu citra wajah pada bagian pengujian citra.

\subsubsection{Validasi Silang Grid Search kernel linier dengan variasi LBP}

Validasi silang yang pertama adalah validasi silang Grid Search kernel linier. LBP memiliki parameter jumlah titik dan jari-jari yang akan divariasikan dengan validasi silang grid search klasifikasi SVM dengan kernel linier dan parameternya yaitu $C$. LBP yang akan diuji adalah $L B P_{8,1}^{u 2}$, $L B P_{8,2}^{u 2}$ dan $L B P_{16,2}^{u 2}$. Variasi parameter $C$ yang digunakan yaitu $10^{2}, 10^{3}, 10^{4}, 10^{5}$
Tabel 2. Hasil pengujian citra latih menggunakan Grid Search dengan kernel linier.

\begin{tabular}{cccc}
\hline \multirow{2}{*}{ Jenis LBP } & \multicolumn{2}{c}{ Parameter Kernel } & \multirow{2}{*}{ Akurasi } \\
& $C$ & - & $52,3 \%$ \\
& $10^{2}$ & - & $80,0 \%$ \\
$L B P_{8,1}^{u 2}$ & $10^{3}$ & - & $90,7 \%$ \\
& $10^{4}$ & - & $89,7 \%$ \\
\hline & $10^{5}$ & - & $53,3 \%$ \\
& $10^{2}$ & - & $82,3 \%$ \\
$L B P_{8,2}^{u 2}$ & $10^{3}$ & - & $89,0 \%$ \\
& $10^{4}$ & - & $89,7 \%$ \\
& $10^{5}$ & & \\
\hline \multirow{2}{*}{$L B P_{16,2}^{u 2}$} & $10^{2}$ & - & $33,0 \%$ \\
& $10^{3}$ & - & $96,7 \%$ \\
& $10^{4}$ & - & $90,7 \%$ \\
\hline
\end{tabular}

Tabel 2 menunjukkan hasil validasi silang grid search untuk pengklasifikasi SVM dengan kernel linier serta variasi nilai LBP dan parameter kernel. Nilai akurasi tertinggi untuk $L B P_{8,1}^{u 2}$ sebesar $90,7 \%$ dengan nilai $C$ sebesar $10^{4}$. Nilai akurasi tertinggi untuk $L B P_{8,2}^{u 2}$ sebesar $89,7 \%$ pada nilai $C$ sebesar $10^{5}$ dan $10^{6}$. Nilai akurasi tertinggi untuk $L B P_{16,2}^{u 2}$ sebesar $91.3 \%$ dengan nilai $C$ sebesar $10^{4}$.

Nilai $C$ pada SVM digunakan untuk mengontrol trade off antara margin hyperplane dan error klasifikasi. Semakin besar nilai $C$ akan meningkatkan tingkat akurasi klasifikasi pelatihan karena nilai $C$ yang besar akan memperbanyak jumlah support vector dan memperkecil margin hyperplane, namun memperkecil margin hyperplane akan meningkatkan tingkat error klasifikasi. Sebaliknya, semakin kecil nilai $C$ akan menurunkan tingkat akurasi klasifikasi pelatihan karena mengurangi jumlah support vector, yang memperbesar margin hyperplane dan mengurangi tingkat error klasifikasi.

\subsubsection{Validasi Silang Grid Search kernel RBF dengan variasi LBP}

Validasi silang yang kedua adalah validasi silang Grid Search kernel RBF. LBP memiliki parameter jumlah titik dan jari-jari yang akan divariasikan dengan validasi silang grid search klasifikasi SVM dengan kernel RBF dan parameternya yaitu $C$ dan $\gamma$. LBP yang akan diuji adalah $L B P_{8,1}^{u 2}, L B P_{8,2}^{u 2}$ dan $L B P_{16,2}^{u 2}$. Variasi parameter $C$ yang digunakan yaitu $10^{3}, 10^{4}, 10^{5}, 10^{6}$, sedangkan variasi parameter $\gamma$ yang digunakan adalah $10^{-2}, 10^{-1}, 10^{0}, 10^{1}, 10^{2}$ 
TRANSIENT, VOL. 7, NO. 1, MARET 2018, ISSN: 2302-9927, 128

Tabel 3. Hasil pengujian citra latih menggunakan Grid Search dengan kernel linier

\begin{tabular}{|c|c|c|c|}
\hline \multirow{2}{*}{ Jenis LBP } & \multicolumn{2}{|c|}{ Parameter Kernel } & \multirow{2}{*}{ Akuras } \\
\hline & $C$ & $\gamma$ & \\
\hline & & $10^{-2}$ & $18,7 \%$ \\
\hline & & $10^{-1}$ & $68,3 \%$ \\
\hline & $10^{3}$ & $10^{0}$ & $85,3 \%$ \\
\hline & & $10^{1}$ & $90,7 \%$ \\
\hline & & $10^{2}$ & $88,7 \%$ \\
\hline & & $10^{-2}$ & $68,3 \%$ \\
\hline & & $10^{-1}$ & $85,3 \%$ \\
\hline & $10^{4}$ & $10^{0}$ & $90,7 \%$ \\
\hline & & $10^{1}$ & $89,3 \%$ \\
\hline & & $10^{2}$ & $88,7 \%$ \\
\hline \multicolumn{4}{|l|}{$L B P_{8,1}^{u 2}$} \\
\hline & & $10^{-2}$ & $85,0 \%$ \\
\hline & & $10^{-1}$ & $91,0 \%$ \\
\hline & $10^{5}$ & $10^{0}$ & $89,7 \%$ \\
\hline & & $10^{1}$ & $89,3 \%$ \\
\hline & & $10^{2}$ & $88,7 \%$ \\
\hline & & $10^{-2}$ & $90,7 \%$ \\
\hline & & $10^{-1}$ & $89,7 \%$ \\
\hline & $10^{6}$ & $10^{0}$ & $89,7 \%$ \\
\hline & & $10^{1}$ & $89,3 \%$ \\
\hline & & $10^{2}$ & $88,7 \%$ \\
\hline & & $10^{-2}$ & $18,7 \%$ \\
\hline & & $10^{-1}$ & $68,3 \%$ \\
\hline & $10^{3}$ & $10^{0}$ & $85,3 \%$ \\
\hline & & $10^{1}$ & $90,7 \%$ \\
\hline & & $10^{2}$ & $88,7 \%$ \\
\hline & & $10^{-2}$ & $68,3 \%$ \\
\hline & & $10^{-1}$ & $87,3 \%$ \\
\hline & $10^{4}$ & $10^{0}$ & $89,3 \%$ \\
\hline & & $10^{1}$ & $88,7 \%$ \\
\hline & & $10^{2}$ & $89,0 \%$ \\
\hline \multicolumn{4}{|l|}{$L B P_{8,2}^{u 2}$} \\
\hline & & $10^{-2}$ & $87,3 \%$ \\
\hline & & $10^{-1}$ & $89,3 \%$ \\
\hline & $10^{5}$ & $10^{0}$ & $89,3 \%$ \\
\hline & & $10^{1}$ & $88,7 \%$ \\
\hline & & $10^{2}$ & $89,0 \%$ \\
\hline & & $10^{-2}$ & $89,0 \%$ \\
\hline & & $10^{-1}$ & $89,7 \%$ \\
\hline & $10^{6}$ & $10^{0}$ & $89,3 \%$ \\
\hline & & $10^{1}$ & $88,7 \%$ \\
\hline & & $10^{2}$ & $89,0 \%$ \\
\hline & & $10^{-2}$ & $17,3 \%$ \\
\hline & & $10^{-1}$ & $49,7 \%$ \\
\hline & $10^{3}$ & $10^{0}$ & $82,0 \%$ \\
\hline & & $10^{1}$ & $90,0 \%$ \\
\hline & & $10^{2}$ & $92,0 \%$ \\
\hline \multicolumn{4}{|l|}{$L B P_{16,2}^{u 2}$} \\
\hline & & $10^{-2}$ & $49,7 \%$ \\
\hline & & $10^{-1}$ & $82,7 \%$ \\
\hline & $10^{4}$ & $10^{0}$ & $90,3 \%$ \\
\hline & & $10^{1}$ & $90,7 \%$ \\
\hline & & $10^{2}$ & $92,0 \%$ \\
\hline
\end{tabular}

Tabel 3. (lanjutan)

\begin{tabular}{cccc}
\hline \multirow{2}{*}{ Jenis LBP } & \multicolumn{2}{c}{ Parameter Kernel } & Akurasi \\
\hline & $C$ & $10^{-2}$ & $82,7 \%$ \\
& & $10^{-1}$ & $90,3 \%$ \\
& \multirow{3}{*}{$10^{5}$} & $10^{0}$ & $91,0 \%$ \\
& & $10^{1}$ & $90,7 \%$ \\
$L B P_{16,2}^{u 2}$ & & $10^{2}$ & $92,0 \%$ \\
& & $10^{-2}$ & \\
& & $10^{-1}$ & $90,3 \%$ \\
& \multirow{2}{*}{$10^{6}$} & $10^{0}$ & $90,7 \%$ \\
& & $10^{1}$ & $90,7 \%$ \\
& & $10^{2}$ & $92,0 \%$ \\
\hline
\end{tabular}

Tabel 3 menunjukkan hasil validasi silang grid search untuk pengklasifikasi SVM dengan kernel RBF serta variasi nilai LBP dan parameter kernel. Nilai akurasi tertinggi untuk $L B P_{8,1}^{u 2}$ sebesar $91,0 \%$. Nilai akurasi tertinggi untuk $L B P_{8,2}^{u 2}$ sebesar $89,7 \%$. Nilai akurasi tertinggi $L B P_{16,2}^{u 2}$ sebesar $92,0 \%$.

Parameter $C$ pada kernel RBF memiliki pengaruh yang sama seperti pada kernel linier, semakin besar nilai $C$ maka akurasinya akan semakin naik untuk nilai $\gamma$ yang sama. Parameter $\gamma$ pada kernel RBF juga berpengaruh pada akurasi pengujian validasi silang grid search, untuk nilai $C$ yang sama semakin besar nilai $\gamma$ maka nilai akurasinya juga akan meningkat. Tabel 3. juga menunjukkan setelah nilai akurasinya tertinggi, jika nilai $\gamma$ dinaikkan lagi maka akurasinya akan sedikit menurun.

\subsection{Pengujian Model terhadap Data Latih}

Pengujian model terhadap data latih adalah pengujian citra yang sebelumnya sudah dilatih dan disimpan pada suatu model. Model yang digunakan berasal dari hasil terbaik dari validasi silang grid search. Data latih yang digunakan terdiri atas 15 wajah dan masing-masing wajah terdiri dari 25 citra. Hasil pengujian model terhadap data latih dapat dilihat pada Tabel 4.

Tabel 4. Hasil pengujian terhadap data latih dengan parameter kernel terbaik.

\begin{tabular}{lcccc}
\hline \multirow{2}{*}{ Kernel } & \multirow{2}{*}{ LBP } & \multicolumn{2}{c}{ Parameter Kernel } & \multirow{2}{*}{ Akurasi Data Latih } \\
& & $C$ & $\gamma$ & $100,0 \%$ \\
Linier & $L B P_{8,2}^{u 2}$ & $10^{5}$ & - & $100,0 \%$ \\
RBF & $L B P_{16,2}^{u 2}$ & $10^{3}$ & $10^{2}$ & \\
\hline
\end{tabular}

Tabel 4 menunjukkan hasil akurasi untuk pengujian terhadap data latih untuk kedua kernel sebesar 100,0\% dari total 375 citra wajah dalam data latih. Hasil akurasi yang sudah mencapai nilai $100,0 \%$ menunjukkan bahwa pelatihan telah berjalan dengan baik karena semua data latih dapat dikenali oleh model pengklasifikasi. 


\subsection{Pengujian Model terhadap Data Uji}

Pengujian citra wajah data uji bertujuan untuk mencari nama individu dari citra wajah yang belum dikenali atau diklasifikasi. Model klasifikasi yang digunakan untuk menguji citra wajah yang belum dikenali menggunakan model terbaik dari hasil validasi silang grid search dan pengujian terhadap data latih. Data uji yang digunakan terdiri dari 15 wajah dengan jumlah citra wajah tiap individu 5. Hasil dari pengujian ini adalah nama individu untuk citra wajah yang diuji.

Hasil pengujian akan digunakan untuk mengetahui kinerja parameter terbaik pada kernel linier dan kernel RBF dalam pengujian citra wajah yang belum dikenali. Hasil pengujian citra wajah dapat ditampilkan pada Tabel 5.

Tabel 5. Hasil pengujian citra wajah menggunakan kernel linier dan kernel RBF

\begin{tabular}{ccccc}
\hline Kernel & $\begin{array}{l}\text { Jumlah citra } \\
\text { uji }\end{array}$ & $\begin{array}{c}\text { Jumlah } \\
\text { pengenalan } \\
\text { benar }\end{array}$ & $\begin{array}{c}\text { Jumlah } \\
\text { pengenalan } \\
\text { salah }\end{array}$ & Akurasi \\
\hline Linier & 75 & 72 & 3 & $96,0 \%$ \\
RBF & 75 & 72 & 3 & $96,0 \%$ \\
\hline
\end{tabular}

Tabel 5 menunjukkan nilai akurasi yang sama untuk kedua kernel yaitu sebesar 96,0\% dari 75 citra wajah yang diuji. Hasil pengujian citra pada Tabel 4.4 yang lebih besar dari $90,0 \%$ menunjukkan bahwa program yang dirancang sudah berjalan dengan baik.

\subsubsection{Pengujian Citra Wajah Variasi Ekspresi}

Pengujian citra wajah variasi ekspresi ini dilakukan untuk mencari akurasi keberhasilan pengenalan dari 15 individu berbeda dengan variasi ekspresi wajah yang berbeda, yaitu ekspresi gembira, sedih, terkejut, netral, dan mata tertutup. Pada Gambar 4 ditampilkan grafik nilai akurasi keberhasilan pengenalannya.

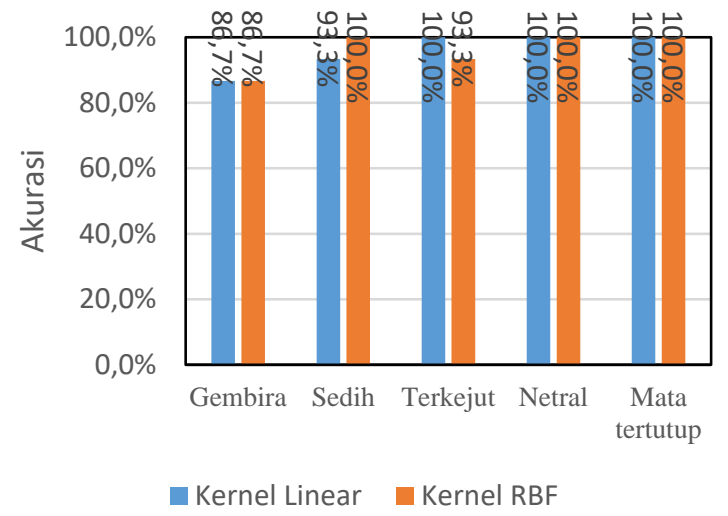

Gambar 4. Grafik perbandingan akurasi pengenalan citra uji dengan berbagai variasi ekspresi

Grafik pada Gambar 4 menunjukkan bahwa hasil terendah pengujian citra uji adalah pada pengujian citra uji ekspresi gembira yaitu $86,6 \%$ untuk kernel linier dan RBF. Sementara hasil pengujian citra uji tertinggi yaitu 100,0\% pada pengujian citra uji ekspresi sedih dengan kernel $\mathrm{RBF}$, ekspresi terkejut dengan kernel linier, ekspresi netral dan mata tertutup untuk kedua kernel. Hasil pengujian secara keseluruhan menunjukkan bahwa sistem pengenalan wajah yang telah dirancang sudah berjalan dengan baik karena nilai akurasinya sudah lebih besar dari 90,0\%, namun untuk akurasi pengujian ekspresi gembira yang sebesar $86,6 \%$ belum mencapai akurasi $90,0 \%$ sesuai target spesifikasi sistem. Hal tersebut disebabkan oleh data pelatihan yang kebanyakan berupa citra wajah dengan ekspresi netral, hal ini juga menjelaskan mengapa akurasi untuk pengujian ekspresi netral dan mata tertutup sebesar $100,0 \%$. Akurasi untuk pengujian ekspresi sedih dan terkejut lebih tinggi dibanding ekspresi gembira yaitu sebesar 93,3\% dan 100,0\% dikarenakan pada ekspresi sedih dan terkejut tidak terjadi perubahan raut muka yang terlalu besar dibandingkan ekspresi gembira dari ekspresi wajah netral.

\subsection{Pengujian Data Uji Berderau Poisson}

Pengujian citra wajah berderau bertujuan untuk mengetahui kinerja sistem jika citra uji diberi derau. Jenis derau yang digunakan adalah derau Poisson atau shot noise. Data uji yang digunakan terdiri dari 15 wajah dengan jumlah citra wajah tiap individu 5. Hasil dari pengujian ini adalah nama individu untuk citra wajah yang diuji. Hasil pengujian citra wajah dapat ditampilkan pada Tabel 6.

Tabel 6. Hasil pengujian citra wajah dengan derau Poisson menggunakan kernel linier dan kernel $\mathrm{RBF}$

\begin{tabular}{ccccc}
\hline Kernel & $\begin{array}{l}\text { Jumlah citra } \\
\text { uji }\end{array}$ & $\begin{array}{c}\text { Jumlah } \\
\text { pengenalan } \\
\text { benar }\end{array}$ & $\begin{array}{l}\text { Jumlah } \\
\text { pengenalan } \\
\text { salah }\end{array}$ & Akurasi \\
\hline Linier & 75 & 17 & 58 & $22,7 \%$ \\
RBF & 75 & 8 & 67 & $10,7 \%$ \\
\hline
\end{tabular}

Berdasarkan Tabel 6. dapat dilihat nilai akurasi pengenalan untuk citra berderau pada kedua kernel sangat rendah yaitu $22,7 \%$ dan $10,7 \%$ dan tidak mencapai spesifikasi sistem yang diinginkan. Nilai akurasi pengenalan yang sangat rendah ini disebabkan karena LBP sensitif terhadap derau, sehingga ketika citra uji berderau diekstraksi cirinya akan menghasilkan vektor ciri yang sangat berbeda dibandingkan vektor ciri citra uji tanpa derau.

\section{Kesimpulan}

Berdasarkan hasil pengujian yang telah dilakukan, sistem pengenalan wajah menggunakan ekstraksi ciri LBP telah berjalan dengan baik. Model terbaik untuk kernel linier dibangun dengan $L B P_{8,2}^{u 2}$ dan parameter $C=10^{5}$. Model terbaik untuk kernel RBF dibangun dengan $L B P_{16,2}^{u 2}$ dan parameter $C=10^{3}$ dan $\gamma=10^{2}$ Nilai akurasi untuk pengujian dengan data latih untuk kedua kernel sebesar $100,0 \%$ dan nilai akurasi untuk pengujian dengan data uji 
sebesar 96,0\%. Pada pengujian ekspresi wajah, akurasi tertinggi $100,0 \%$ pada ekspresi sedih, netral, mata tertutup dengan kernel linier dan ekspresi terkejut, netral, mata tertutup dengan kernel RBF. Akurasi terendah untuk pengujian citra uji ekspresi wajah pada ekspresi gembira yaitu $86,6 \%$ pada kedua kernel. Nilai akurasi pengenalan untuk citra berderau pada untuk kernel linier sebesar $22,7 \%$ dan untuk kernel RBF sebesar 10,7\%

\section{Referensi}

[1]. Anil K. Jain, Patrick Flynn, dan Arun A.Ross, Handbook of Biometrics, USA: Springer Science, 2008.

[2]. Arif Muntasa, Mochamad Kautshar Sophan. "Pengenalan Citra Wajah Menggunakan Support Vector Machine Berbasis Segmentasi 2D-Discrete Cosine Transform", Seminar Nasional Electrical, Informatics, and IT's Educations, 2009.

[3]. Yuan Luoa, Cai-ming Wu, Yi Zhang. "Facial expression recognition based on fusion feature of PCA and LBP with SVM", Optik - International Journal for Light and Electron Optics, vol 124, Issue 17, September 2013, Pages 2767-2770
[4]. P. Viola dan M. Jones, "Rapid Object Detection using a Boosted Cascade of Simple Features," Conf. Comput. Vis. PATTERN Recognit., 2001.

[5]. T. Ojala, M. Pietikainen dan D. Harwood, "A comparative study of texture measures with classification based on feature distributions" Pattern Recognition vol. 29, 1996.

[6]. Christopher J.C. Burges, " A Tutorial On Support Vector Machines For Pattern Recognition ", Data Mining and Knowedge. Discovery, vol. 2, no. 2, pp. 121-167, 1998.

[7]. B. Scholkopf and A. J. Smola, Learning with Kernels Support Vector Machines, Regularization, Optimization, and Beyond. Cambridge, Massachusetts: The MIT Press, 2002.

[8]. R. Kohavi, "A Study of Cross-Validation and Bootstrap for Accuracy Estimation and Model Selection," Int. Jt. Conf. Artif. Intell., vol. 5, 1995. 